\title{
Fossil Cenozoic crassatelline bivalves from Peru: New species and generic insights
}

Thomas J. DeVries

Acta Palaeontologica Polonica 61 (3), 2016: 661-688 doi:http://dx.doi.org/10.4202/app.00228.2015

Discoveries of new fossil Cenozoic crassatellines in Peru provide a new phylogenetic perspective on "large" Neogene genera, in which four lineages are considered to have arisen independently from different Paleogene Crassatella ancestors. Latest Oligocene and early Miocene species of the new genus Tilicrassatella gen. nov.-T. ponderosa, T. torrens sp. nov., and T. sanmartini sp. nov. from the East Pisco Basin—probably evolved from the late Eocene species, Crassatella rafaeli sp. nov., which itself differed in significant respects from slightly older species of the East Pisco Basin, C. neorhynchus and C. pedroi sp. nov. The paciphilic genus, Hybolophus , is raised to full generic status. Added to its ranks are the East Pisco Miocene species H. maleficae sp. nov., H. terrestris sp. nov., and the oldest species of the genus, the late Eocene or Oligocene $H$. disenum sp. nov. from the Talara Basin of northern Peru. Kalolophus gen. nov., encompassing circum-Caribbean fossil species, the extant species, $K$. speciosus, and the trans-isthmus species, $K$. antillarum, appears to have evolved from the early Oligocene Floridian species, Crassatella portelli sp. nov. The genus Marvacrassatella is a western Atlantic Miocene lineage most likely descended from Kalolophus. The genus Eucrassatella is restricted to Australian and New Zealand taxa. The Eocene New Zealand species, Spissatella media, is transferred to Eucrassatella and deemed a candidate for the most recent common ancestor of younger Eucrassatella and all Spissatella species. In the southern Pacific Ocean, the circum-Caribbean region, and tropical western America, crassatelline lineages developed one or more of the following characters: large resilifers, smooth ventral margins, and an extended left anterior cardinal tooth. Some of these late Paleogene convergent character changes might have countered increased shear forces exerted on the crassatelline valves while burrowing into finer-grained and more cohesive sediments in deeper or quieter water.

Key words: Bivalvia, Crassatellidae, evolution, Florida, New Zealand, Peru.

Thomas J. DeVries [tomdevrie@aol.com], Burke Museum of Natural History and Culture, University of Washington, Box 353010, Seattle, Washington 98195 USA; correspondence address: Box 13061 Burton, Washington 98013, USA. 
This is an open-access article distributed under the terms of the Creative Commons Attribution License (for details please see creativecommons.org), which permits unrestricted use, distribution, and reproduction in any medium, provided the original author and source are credited.

Forif Full text $(2,071.1 \mathrm{kB})$ ।

FoF Supplementary file $(85.1 \mathrm{kB})$ 